\title{
Durability testing of tangential-rotary picks made of different materials
}

\begin{abstract}
This paper presents information on the current most-widely-used cutting heads; i.e., tangential-rotary picks. It describes their applications, design, methods for improving their durability, as well as problems related to their performance. The main body of the paper deals with the results of the durability testing of tangential-rotary picks made of different materials and hardfaced or machined in ways that lead to an increase in their durability. The picks selected for the tests were standard, commercially-available, and prototypical ones. The paper also presents a state-of-the-art laboratory test stand to research the cutting process or rotation drilling with the use of a single cutting tool or cutting drum (the property of the Department of Mining, Dressing, and Transport Machines of the AGH UST in Krakow).
\end{abstract}

Key words: mechanical mining, hard rocks, tangential - rotary pick, durability, tools wear, test stand

\section{INTRODUCTION}

Tunneling excavation and longwall extraction are most frequently performed by means of mechanical mining methods, which involve the direct impact of a cutting tool or an assembly of cutting tools on rock. The most-widely-applied methods in mining operations are milling with longwall shearer loaders and plowing with coal plows, which are performed with the use of cutting tools (shearer picks and plow cutters) [1-3].

Currently, roadheaders, longwall shearer loaders and even vertical shaft mining machines are most commonly using tangential - rotary picks. Due to their increased durability, these picks have almost completely replaced the formerly used solutions; i.e., tangent picks and radial picks. They have had a significant influence on reducing the time necessary for their replacement as well as decreasing wear on the tool holders and cutting heads [3-5].

Tangential-rotary picks (which are fitted in cutting drums of longwall shearer loaders - Fig. 1a) are characterized by their significant body length $\left(L_{n} \geq 80 \mathrm{~mm}\right)$ and slenderness. The pick edges of such picks are equipped with sintered carbide inserts with a cone angle of $2 \beta_{u} \geq 93^{\circ}$. Also, the shaft inserted into the tool holder is longer and can be graded. The pick is protected against slipping out of the tool holder by means of different types of pins, rings, and bushings. The picks of roadheaders (Fig. 1b) are mounted in tool holders welded to the cutting head accommodated on the arm of this machine. Compared to the picks used in shearer loaders, they are shorter and less slender, and the carbide inserts used to manufacture their edges have larger cone angles [4-7].

The cutting process performed with tangential-rotary picks requires a tool to have a shape and dimensions enabling the edge that penetrates the rock to a depth of $g_{s}$ to achieve proper astatic angles of cutting. What is particularly important is that the pick edge retains a positive angle of application $\alpha_{r}[1,8]$.

A pick mounted in a tool holder is part of the cutting head (Fig. 2); therefore, astatic angles of cutting $\alpha_{r}$ and $\gamma_{r}$ depend not only on the design parameters of the pick but also on cutting speed $v_{s}$ and advance speed $v_{p}$. It can, therefore, be concluded that, for 
a)

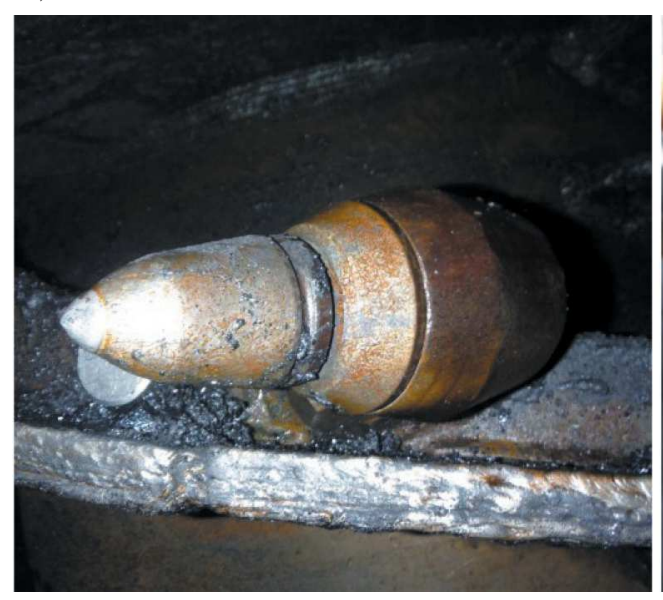

b)

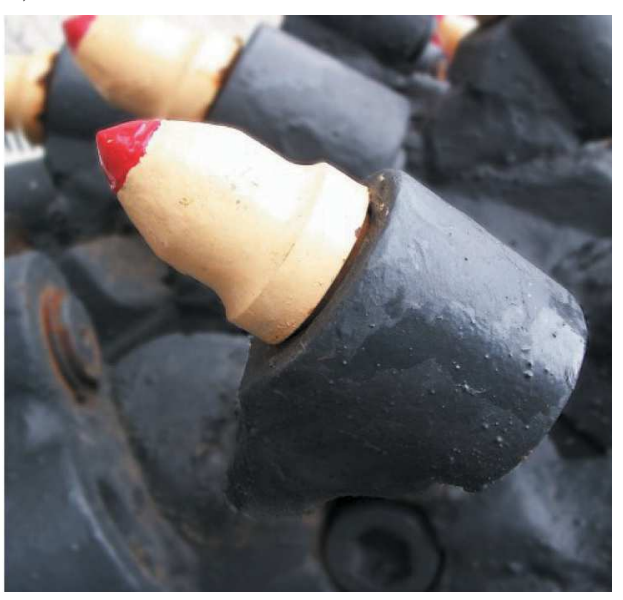

Fig. 1. Tangential-rotary pick mounted on cutting head of: a) shearer loader; b) roadheader

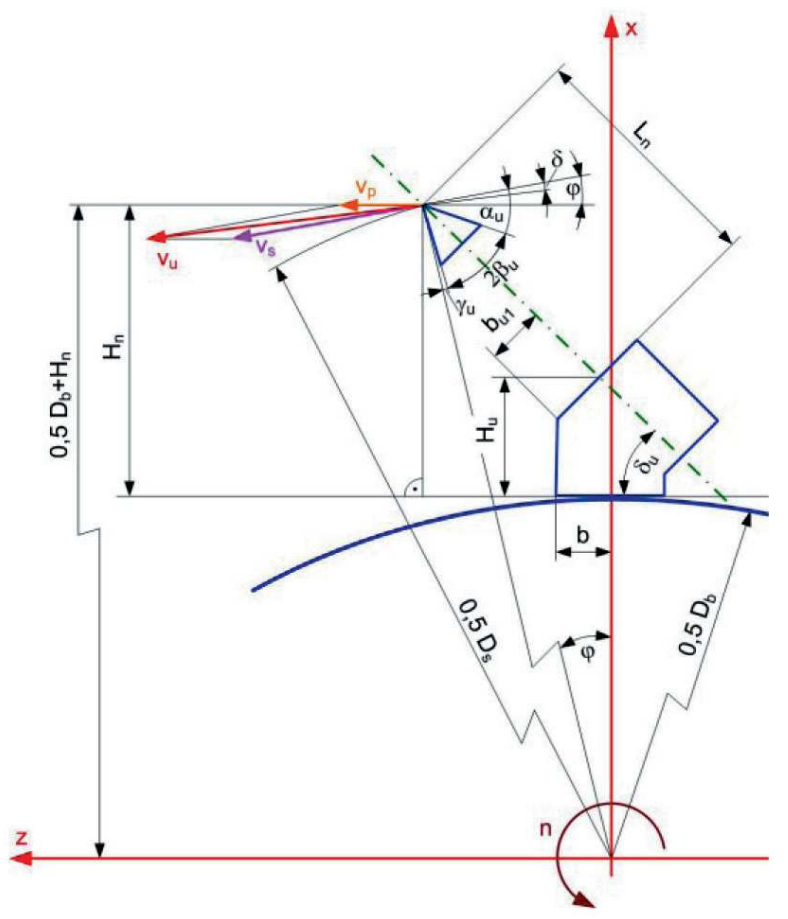

Fig. 2. Parameters of tool holder setup and tangential-rotary pick adjustment on cutting head [6]

a cutting head having diameter $D_{s}$, cutting speed $v_{s}$, advance speed $v_{p}$, height of the tool holder $H_{u}$, and angle $\delta_{u}$, it is necessary to select a tangential-rotary pick of length $L_{n}$ and pick edge angle $2 \beta_{u}$. Then, the remaining design parameters will have to assume such values as to guarantee the most-favorable conditions of cutting. [8-10]. Thus, it is essential to choose such a design and kinematic parameters of the pick that the lowest-possible cutting resistances and maximum-possible durability of the pick are obtained as a result $[1,4,10]$.
A cutting tool is an element that is in direct contact with the mined rock during extraction works. As a result of the mining process, the tool is subjected to excessive wear in the zone that is the interface between this tool and the extracted material. This leads to changes in the geometrical shape of the tool as well as a loss in its weight. Especially, a change in shape and loss in weight are factors that cause the carbide insert to fall out, which means a loss of cutting capacity. Mechanical damage to a tool resulting from incorrect operation or manufacturing flaws is another problem $[3,4,10]$.

The proper choice of design and kinematic parameters along with the pick's manufacture technology and the type of materials used are those factors that condition the proper performance of picks. Thus, to improve the durability of rotary picks, intensive research aimed at the development of optimal materials for both the cutting edges and pick bodies is being carried out.

Currently, the cutting edges are most-commonly made of cemented carbide with cobalt content. However, the edges are made of other materials; e.g., cermet, ceramic sinters, or polycrystalline diamond $[5,7]$. A cermet is a cemented carbide with titanium-based hard particles. The name "cermet" combines the words ceramic and metal. Originally, cermets were composites of $\mathrm{TiC}$ and nickel. Modern cermets are nickel-free and have a designed structure of titanium carbonitride $\mathrm{Ti}(\mathrm{C}, \mathrm{N})$ core particles, a second hard phase of $(\mathrm{Ti}, \mathrm{Nb}, \mathrm{W})(\mathrm{C}, \mathrm{N})$ and a W-rich cobalt binder. In the group of ceramic sinters, we can name oxide ceramics are aluminum-oxide-based $\left(\mathrm{Al}_{2} \mathrm{O}_{3}\right)$ and nitride ceramics primarily containing silicon nitride $\left(\mathrm{Si}_{3} \mathrm{~N}_{4}\right)$. In addition, a polycrystalline diamond 
(PCD) is a composite of diamond particles sintered together with a metallic binder. Diamond is the hardest and, therefore, the most-abrasion-resistant of all materials. As a cutting tool, it has good wear resistance, but it lacks chemical stability at high temperatures and dissolves easily in iron $[5,7,11]$.

Then, a pick of high durability is obtained, assuming that the operational part of the pick protects the carbide insert against falling out at the same time. Therefore, numerous methods for reducing the wear rate of the pick body (and the resulting possibility of losing carbide inserts) are applied [3, 9].

Pick bodies are made of high-impact, high-wear-resistant, and high-abrasive-resistant steels that can additionally undergo carburizing and thermal processing [7, 12]. In order to reduce wear, the conical surface of the pick is also protected by means of plating it with an abrasion-resistant layer performed by welding. Another method involves incorporating an additional cemented carbide ring on the heavy-duty section of the pick body (Fig. 3) [5, 10]. The above-mentioned measures result in an increase in pick durability; however, this fact still needs to be confirmed by laboratory or performance tests.

The measurement of the wear rate of tangential-rotary picks is aimed at determining their durability. The measurements have to be made under identical conditions to make sure that the results are reliable, reproducible, and probabilistic. This will allow for the evaluation of the durability of the pick as well as the comparison of different picks. In industrial conditions, the durability of cutting picks is usually defined as a ratio of the number of replaced picks to the volume of extracted material. Most frequently, it is the number of worn picks necessary to obtain $1000 \mathrm{Mg}$ or $1000 \mathrm{~m}^{3}$ of extracted material. However, under laboratory conditions, the wear rate (durability) of the pick (or picks) is most-effectively determined on the basis of the loss in its (their) weight in relation to the volume of rock specimen extracted with this pick (these picks) [8-10].

This paper presents the results of research which aim was the above-mentioned measurement of the tangential-rotary picks wear, made of different materials. Standard, commercially available, and prototypical picks were compared. The tests were carried out at a special state-of-the-art laboratory stand for investigating the mining process performed by means of cutting or rotary drilling with single cutting tools and mining machinery units belonging to the Chair of Mining, Dressing and Transport Machines of the AGH in Krakow.

\section{SUBJECT OF RESEARCH}

The tests were conducted for eight types of tangential-rotary picks made of different materials, all of which had been hardfaced or machined in order to improve their durability. Apart from the standard picks, all of these picks were prototypical ones (Fig. 4). The length of the operational part of all picks was $90 \mathrm{~mm}$, and the edge angle was $2 \beta_{u}=90^{\circ}$. Seven of these different types were equipped with sintered carbide, while one type was reinforced with a ceramic insert. The tests were performed on the following picks:

- Standard picks, commercially available, with a sintered carbide insert $\phi 22-4$ picks - marked as Commercial 22.
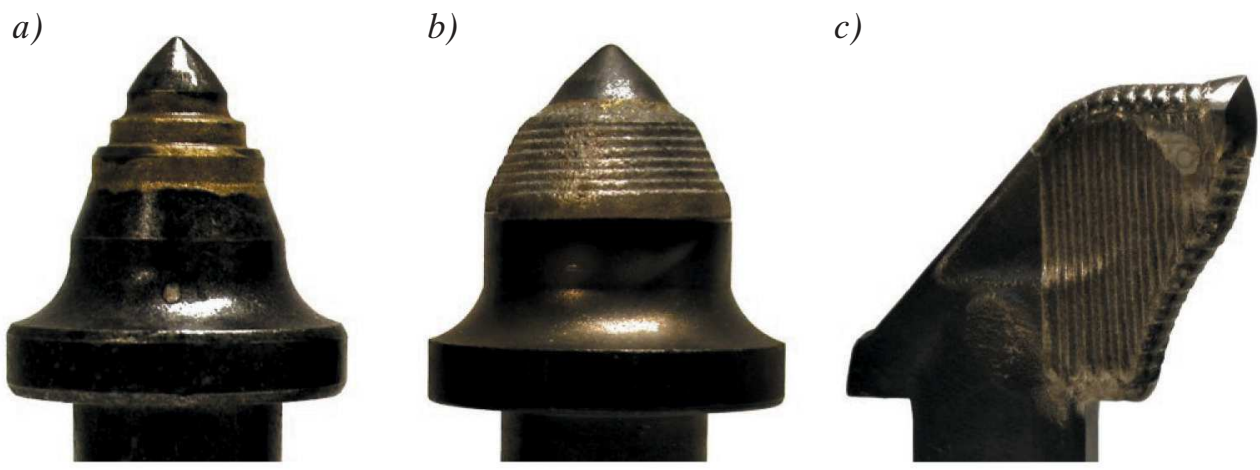

Fig. 3. Methods for increasing durability of pick body: a) tangential-rotary pick with additional ring made of cemented carbide accommodated on attacking part; b) tangential-rotary pick with hard-faced layer welded on; c) radial pick with hard-faced layer welded on [3, 8] 
a)

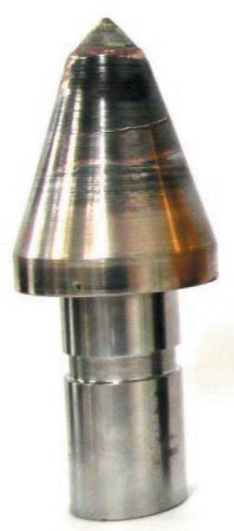

b)

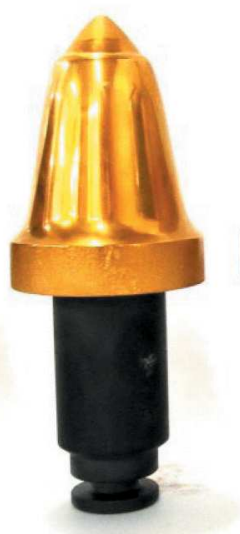

c)

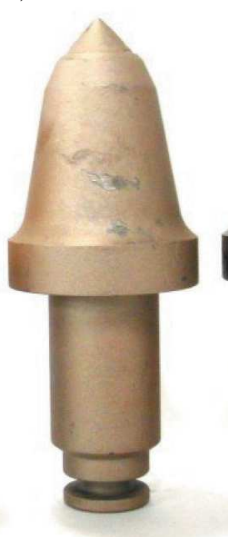

d)

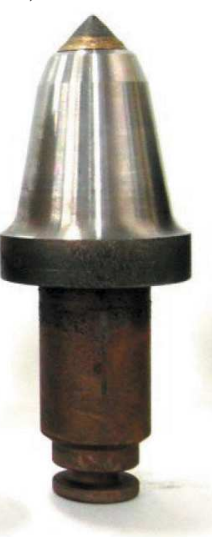

e)

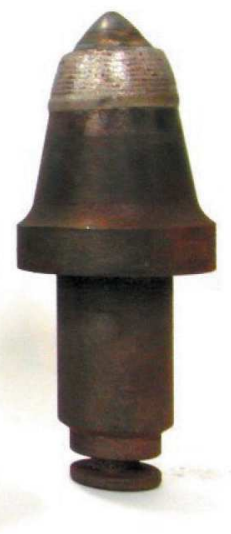

Fig. 4. Selected picks intended for testing: a) Casted 22; b) Gold 25; c) Commercial 22; d) Silver 22; e) Hardfaced 25

- Standard picks, commercially available, with a cemented carbide insert $\phi 25-4$ picks - marked as Commercial 25 (Fig. 4c).

- Laser hardfaced picks with a sintered carbide insert $\phi 22$ (the Commercial 22 picks were used for laser hardfacing) - 4 picks - marked as Hardfaced 22.

- Laser hardfaced picks with a sintered carbide insert $\phi 25$ (the Commercial 25 picks were used for laser hardfacing) - 4 picks - marked as Hardfaced 25 (Fig. 4e).

- Titanium-nitride-coated picks with a sintered carbide insert $\phi 25$ (the Commercial 25 picks were used for hardfacing) - 4 picks - marked as Gold 25 (Fig. 4b).

- Picks with the hardened body with a sintered carbide insert $\phi 25$ (the Commercial 22 picks were used for hardfacing) - 4 picks - marked as Silver 22 (Fig. 4d).

- Casted picks with a sintered carbide insert $\phi 22$ (casted picks, no information on the material used) - 4 picks - marked as Casted 22 (Fig. 4a).

- Casted picks equipped with a ceramic insert instead of cemented carbide (no information on the material used) -4 picks - marked as Ceramic.

\section{RESEARCH PLAN AND METHODOLOGY}

To assess the durability of the picks provided for the tests, the wear rate defined as the total loss in weight of the picks in relation to the volume of the extracted material during the cutting test of an artificial rock sample [8, 9]. The assumed definition of the parameter that defines the durability of picks and the requirements pertaining to testing their wear rate resulted in the approval of the following research plan:

- preparation of a cement-sand sample (cement, sand, aggregates, water) of the specified uniaxial compressive strength (empirically determined),

- preparation of a test disc with proper holders,

- preparation and marking of the picks intended for research and measuring their weight,

- mounting four tangential-rotary picks on the test disc,

- cutting by milling under laboratory conditions at constant advance and cutting speeds,

- dismantling the picks,

- measuring the weight of the picks after the cutting process,

- measuring the volume of the extracted material obtained due to the operation of the tested picks,

- calculating the $\mathrm{C} 2$ factor; i.e., the coefficient defining the wear rate of the picks.

The execution of the approved research plan and methodology necessitated defining (or assuming) the following important parameters related to the cutting process performed with the picks in question:

- cutting a cement-sand sample composed of cement, sand, and basaltic aggregate of a uniaxial compressive strength $R_{c}=22.65 \mathrm{MPa}$ and invariant mass $\gamma_{w}=2.18 \mathrm{Mg} / \mathrm{m}^{3}$,

- advance speed: $v_{p u}=0.01 \mathrm{~m} / \mathrm{min}$,

- number of revolutions of the test disc: $n=42 \mathrm{rpm}$,

- length of the cut: $120 \mathrm{~mm}$,

- web cut: $152 \mathrm{~mm}$,

- outside diameter of the test disc: $\phi 1863 \mathrm{~mm}$.

Following the measurement of the weight of the picks and the volume of the cut material extracted 
with these picks, it is possible to determine the factor characterizing the wear rate of the tested picks. The wear rate of the picks (durability) shall be determined by formula (1):

$$
\mathrm{C} 2=\frac{\Delta m}{m} \cdot \frac{V_{w}}{V_{u}}[-]
$$

where:

C2 - wear rate on the basis of weight,

$\Delta m$ - loss in weight during testing (in the body together with the pick edge) [g],

$m$ - weight of the pick prior to testing [g],

$V_{w}$ - standard volume of the sample $\left[\mathrm{m}^{3}\right]$,

$V_{u}$ - volume of the cut material obtained from the sample during testing $\left[\mathrm{m}^{3}\right]$.

The standard volume of sample $V_{w}$ is assumed arbitrarily. The volume of the sample obtained from cutting during test $V_{u}$ is a calculated value and is determined on the basis of the measured web cut, diameter of the cutting head, and length of the cut [8].

The tests of all types of picks are performed in accordance with the approved methodology and research plan. The following should be noted: the lower the value of the $\mathrm{C} 2$ parameter, the lower the wear rate of the pick. In this case, it is especially recommended to carry out laboratory tests. Such tests have to be conducted on a specially prepared test stand meeting the requirements of the approved methodology [8].

\section{EXECUTION OF RESEARCH}

Prior to testing, all of the picks were checked (in order to note any potential flaws), photographed, and weighed. Next, each set of picks underwent testing on the test stand.

\subsection{Test stand}

Tests were performed on a laboratory test stand for investigating the rock-breaking process by cutting or drilling with single cutting tools or mining machinery units. This is used to perform comprehensive laboratory tests related to the widely-understood rock-cutting process. This particular test stand allows us to perform the cutting process with a particular cutting head on an artificial or natural rock sample under laboratory conditions. The test stand consists of three main subassemblies (Fig. 5):

- drive assembly of the cutting head,

- sample mounting and driving assembly,

- measuring and control system.
The drive assembly of the cutting head is placed on a foundation; it is composed of a $250 \mathrm{~kW} \mathrm{AC} \mathrm{in-}$ duction motor (supply voltage $3 \times 400 \mathrm{~V}$; rated speed $1487 \mathrm{rpm}$ ) that is DTC controlled and powered by an intermediate frequency inverter. The crankshaft torque is transmitted to the shaft of the cutting tool by means of a mechanical gearbox with a ratio of $i=28$. Additionally, a torque-measuring shaft was mounted on the crankshaft. The configuration of the assembly enables the operation of the drive in two ranges: the-so called constant torque control (up to $50 \mathrm{rpm}$ ) and constant power control (up to $120 \mathrm{rpm}$ ). The drive assembly is equipped with a spline at the end on which the cutting tool is mounted.

A rock sample moves longitudinally and transversely in relation to the cutting tool. The longitudinal and transverse motion of the rock sample is forced by hydraulic cylinders, which allow for achieving a feed speed from 0 to $9.9 \mathrm{~m} / \mathrm{min}$, feed force up to $150 \mathrm{kN}$, longitudinal stroke up to $2.5 \mathrm{~m}$, and transverse stroke up to $1.3 \mathrm{~m}$. The length of the rock sample is $2.5 \mathrm{~m}$, its width is $1.3 \mathrm{~m}$, and its height is $2.5 \mathrm{~m}$.

The test stand makes it possible to investigate cutting heads with a maximum diameter of $2.2 \mathrm{~m}$ and a maximum web cut of $1.0 \mathrm{~m}$. The output obtained during the cutting process falls into a hopper moving on guides together with the specimen that is being cut. This solution allows for the uninterrupted disposal of the extracted material (during tests).

The control system and the system of controlling and registering particular values connected with the rock-breaking process are housed in a cab that restricts noise level and pollution. The control system was prepared on the basis of programmable logic controllers (PLCs). Haptic panels and a remote control are used for process visualization and control. The operator is able to change each of the process parameters and preview all of the current values of the registered (measured) quantities. The measuring assembly consists of sensors that allow us to determine the runs of the following:

- longitudinal feed speed,

- transverse feed advance,

- rated speed of the cutting head,

- torque of the cutting resistance,

- longitudinal forces,

- transverse forces.

Additionally, the test stand allows us to measure dust levels during testing and to perform grain-size distribution analyses of the extracted material. 
a)

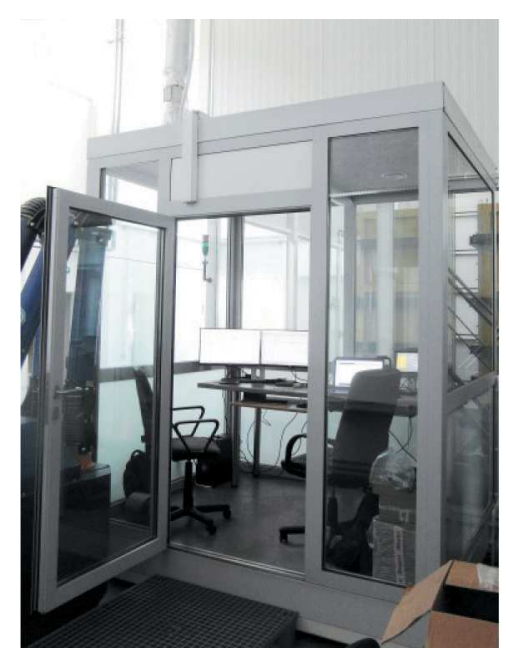

b)

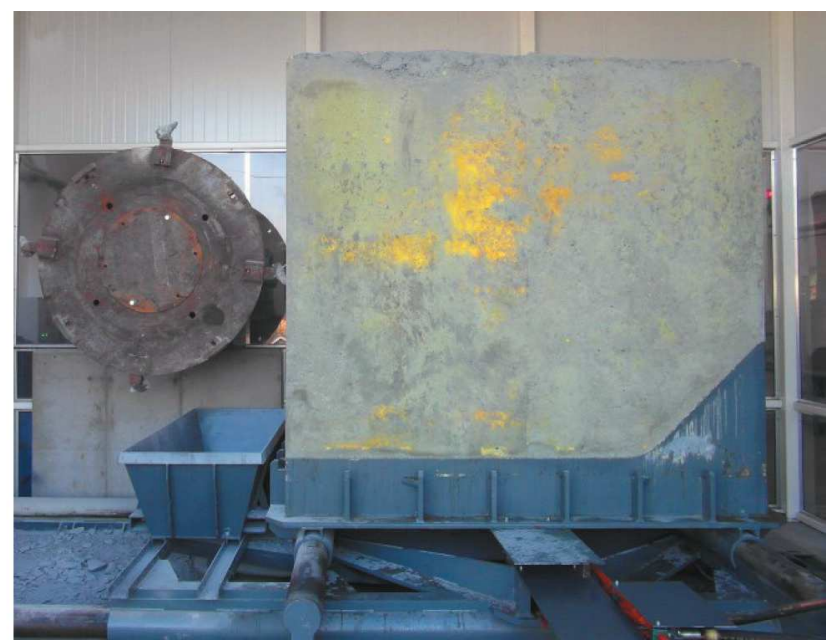

c)

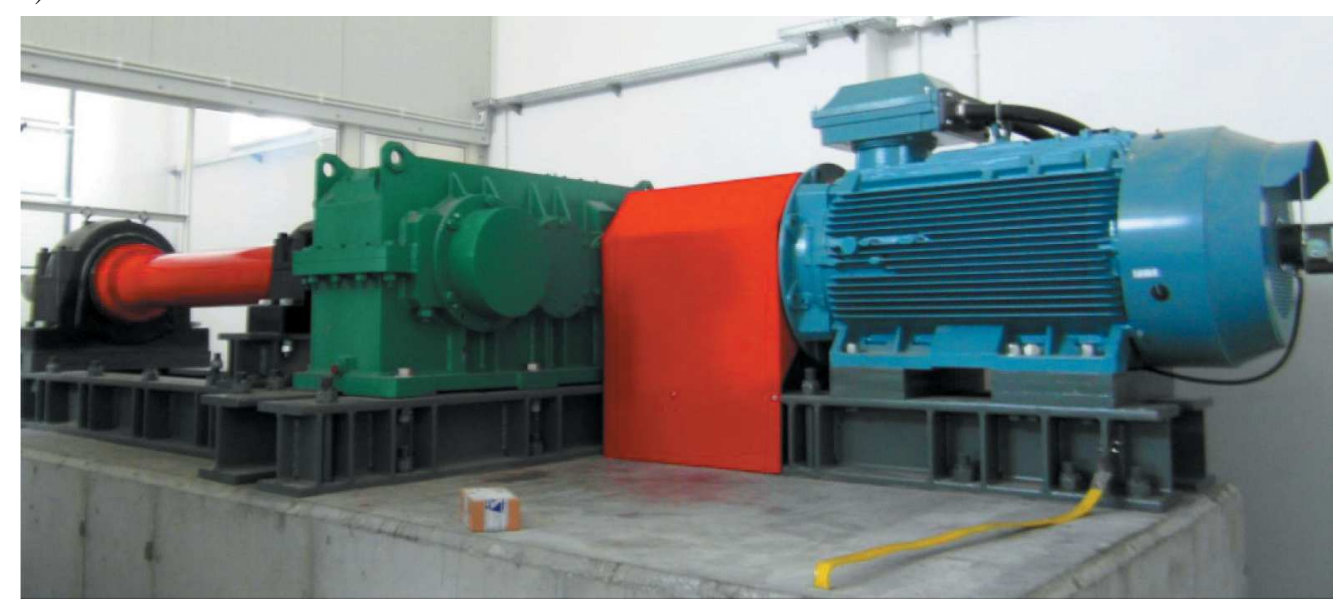

Fig. 5. Laboratory test stand to research cutting process or rotation drilling with use of single cutting tool or cutting head: a) operator ca; b) cement sample with its mounting and drive assembly and cutting head used for testing;

c) drive assembly of cutting head

\subsection{Test procedure}

The tests were conducted for eight sets of picks in accordance with the detailed research plan and approved methodology. Picks on the test disc formed a pick arrangement as shown in Figure 6. The picks were arranged around the perimeter and spaced at $90^{\circ}$ intervals. Each set of picks was mounted in tool holders numbered from 1 to 4 , which were incorporated on the disc. Figure 7 shows the picks mounted in the tool holders prepared for testing in particular test runs.

In Figure 8, selected picks after the cutting process are presented. Next, the picks were prepared for weight measurements; on the basis of the obtained values, the parameters defining the wear rate of particular types of picks were calculated in accordance with the assumed research plan and methodology.

\subsection{Analysis of the test results}

The test results were analyzed on the basis of the measured values and given formulae. Then, they were compared in the so-called measurement record sheets. The table (an example of which is shown below - Table 1) is the principal part of the measurement record sheet. The measurement record sheet for each type of pick consists of two pages. The first page contains information pertaining to the researchers, research execution (date, parameters of the sample), tested picks (marking, weight prior to and following the measurements), volume of the cut sample, $\mathrm{C} 2 \mathrm{pa}$ rameter for each pick, and mean value. On the other page of the measurement record sheet, there are photographs of each pick taken after testing. Three photographs of each pick are taken, each time rotated by $120^{\circ}$ in relation to the pick axis (Fig. 9). 

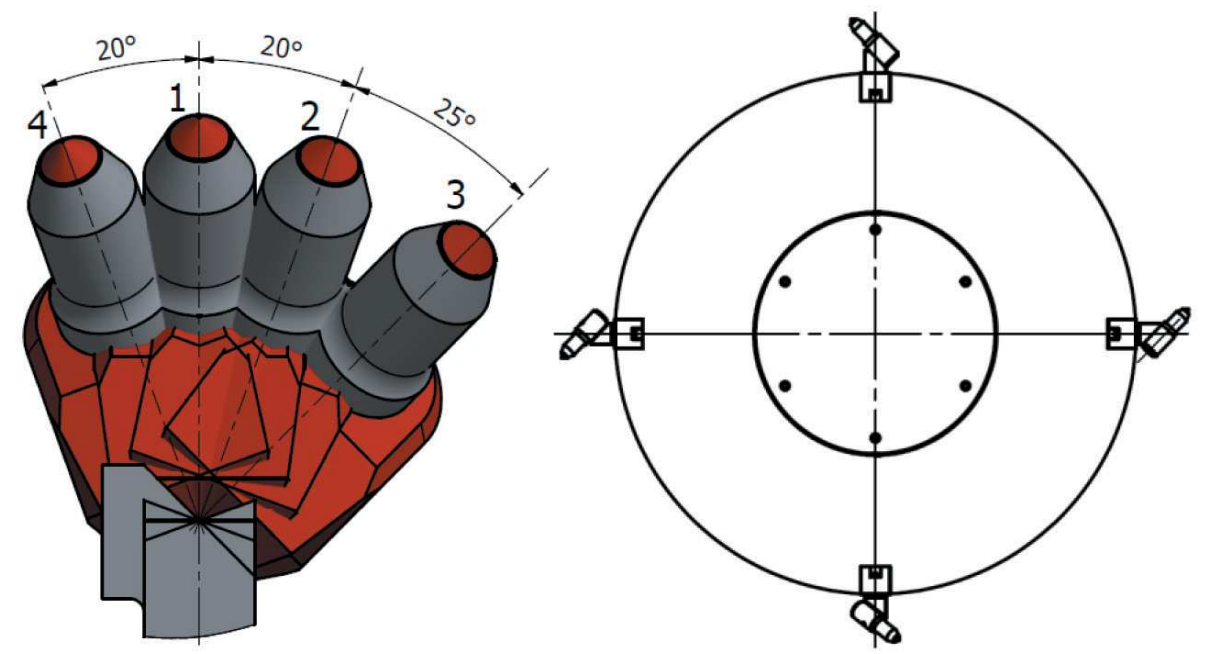

Fig. 6. Scheme of applied pick arrangement with picks marked [8]
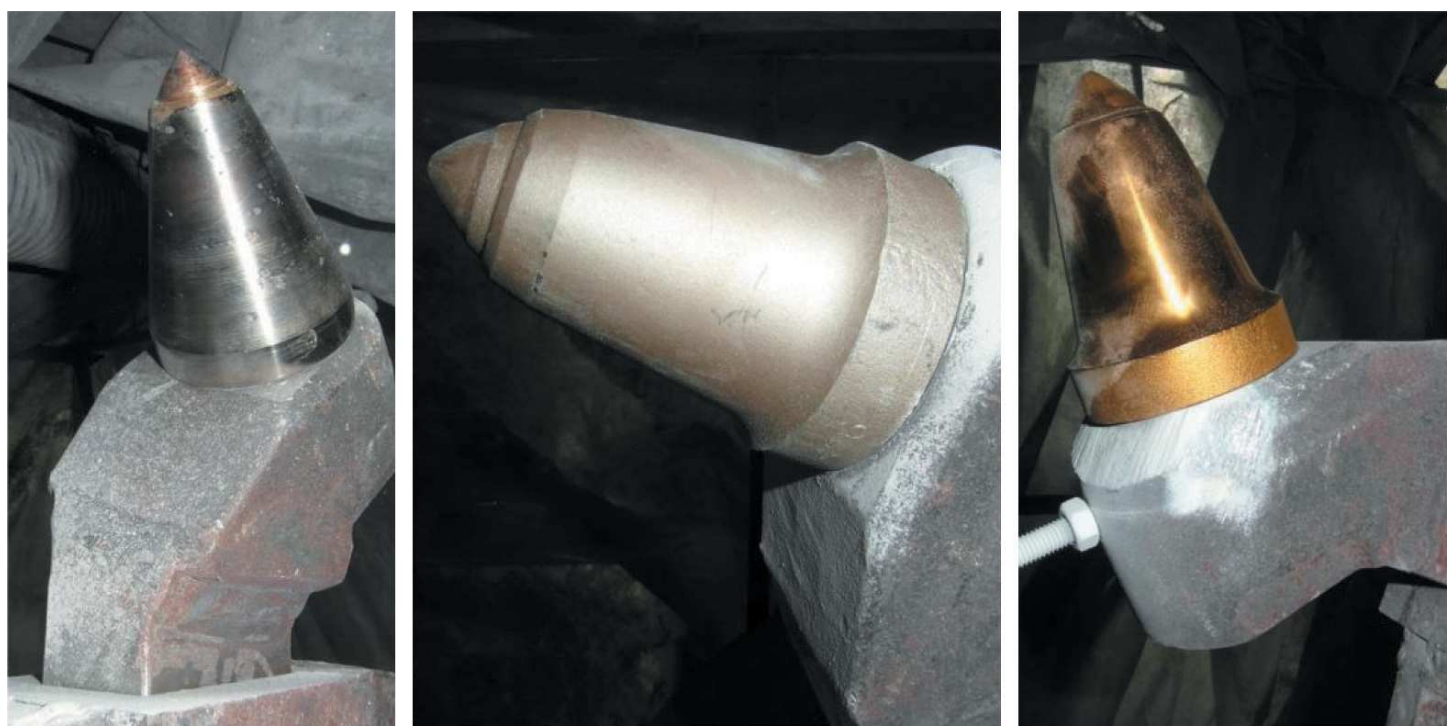

Fig. 7. Examples of tangential-rotary picks prepared for testing

a)

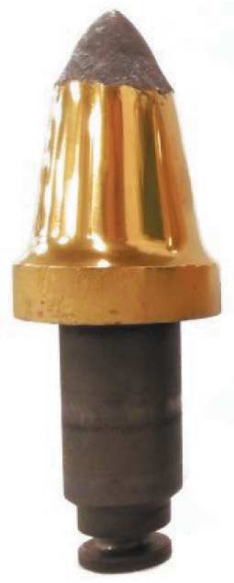

b)

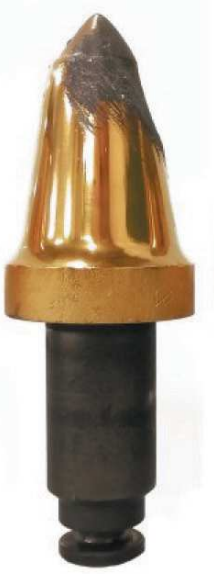

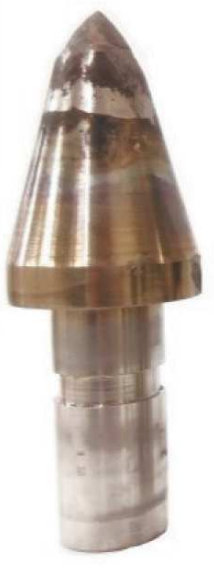

c)
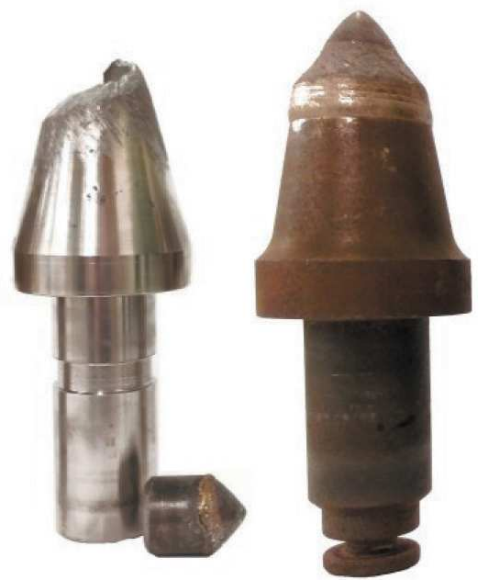

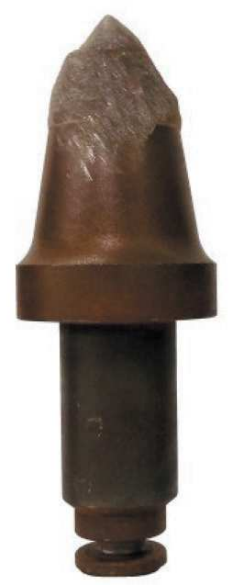

Fig. 8. Selected picks after testing: a) Gold 25; b) Casted 22; c) Hardfaced 25 
Table 1

Comparison of test results and calculated parameters for picks marked as Commercial 22

\begin{tabular}{|c|c|c|c|c|c|c|c|c|c|c|}
\hline \multicolumn{3}{|c|}{$\begin{array}{c}\text { Pick } \\
\text { Commercial } 22\end{array}$} & \multirow{3}{*}{$\begin{array}{c}\text { Before test } \\
\text { Pick weight } \\
\quad m[g]\end{array}$} & \multicolumn{7}{|c|}{ After test, $V_{w}=5 \mathrm{~m}^{3}$} \\
\hline \multirow{2}{*}{ No. } & \multirow{2}{*}{$\begin{array}{c}\text { Marking } \\
\text { of pick }\end{array}$} & \multirow{2}{*}{$\begin{array}{l}\text { Producer } \\
\text { marking }\end{array}$} & & \multirow{2}{*}{$\begin{array}{c}\text { Pick weight } \\
m_{p}[\mathrm{~g}]\end{array}$} & \multirow{2}{*}{$\begin{array}{c}\text { Decline } \\
\text { of pick weight } \\
\Delta m=m-m_{p}[\mathrm{~g}]\end{array}$} & \multicolumn{3}{|c|}{ Photographs } & \multirow{2}{*}{$V_{u}\left[\mathbf{m}^{3}\right]$} & \multirow{2}{*}{ C2 [-] } \\
\hline & & & & & & $\mathbf{0}^{\circ}$ & $120^{\circ}$ & $240^{\circ}$ & & \\
\hline 1 & 1 & - & 1830.14 & 1809.69 & 20.45 & $1-\mathrm{I}$ & 1-II & 1-III & 0.0539 & 1.036 \\
\hline 2 & 2 & - & 1828.49 & 1795.85 & 32.64 & $2-I$ & 2-II & 2-III & 0.0539 & 1.655 \\
\hline 3 & 3 & - & 1828.80 & 1792.85 & 35.95 & 3-I & 3-II & 3-III & 0.0539 & 1.822 \\
\hline 4 & 4 & - & 1828.40 & 1793.48 & 34.92 & 4-I & 4-II & 4-III & 0.0539 & 1.771 \\
\hline \multicolumn{9}{|c|}{ The mean value of the parameter $\mathrm{C} 2$ : } & \multicolumn{2}{|c|}{$\mathrm{C} 2: \mathbf{1 . 5 7 1}$} \\
\hline
\end{tabular}

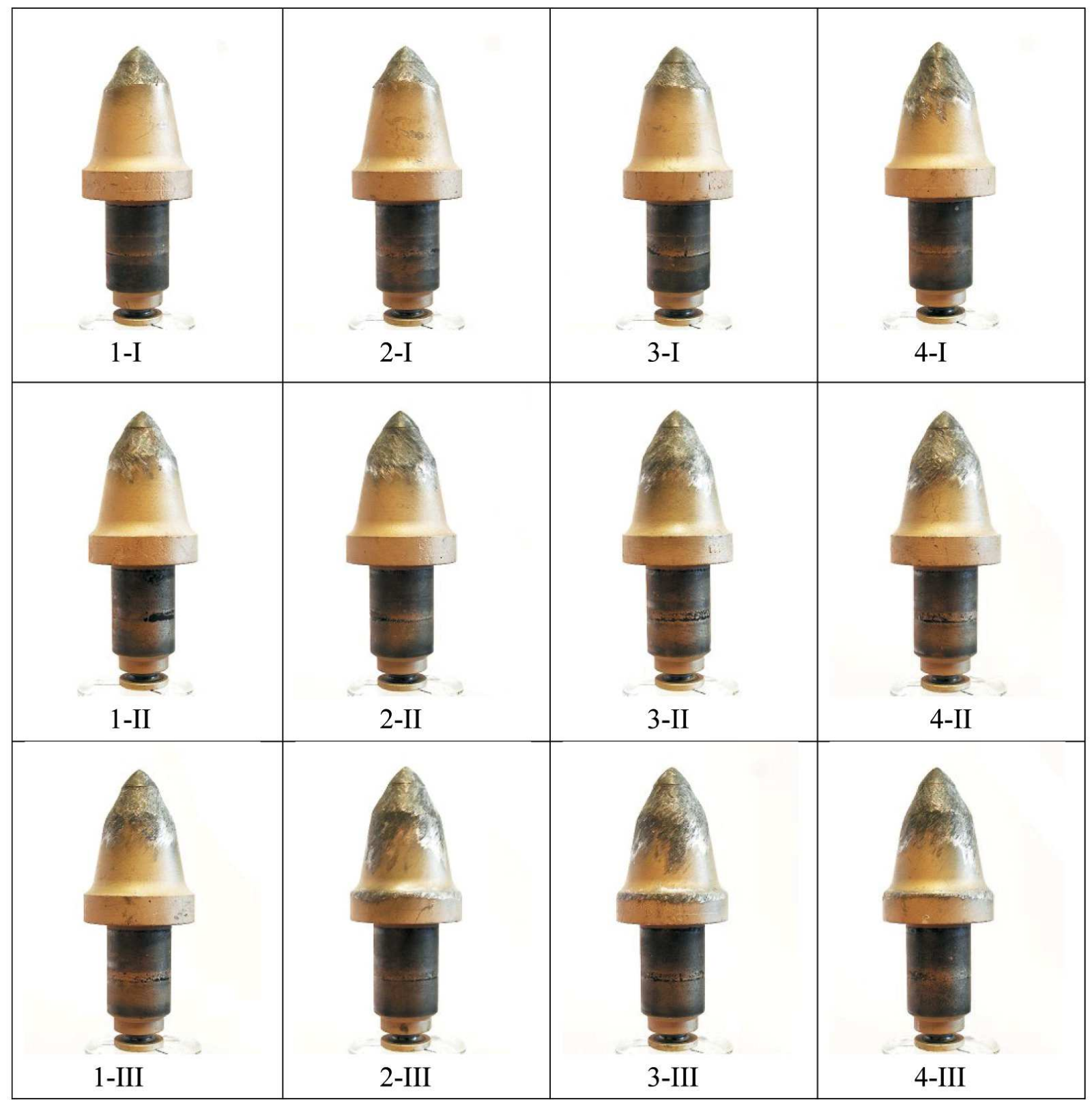

Fig. 9. Photographs of pick marked as Commercial 22 after test made-up each time rotated by $120^{\circ}$ in relation to pick axis 


\section{DURABILITY ASSESSMENT OF THE TESTED PICKS}

Eight cutting tests of the picks were carried out within the framework of wear rate (durability) tests of tangential-rotary picks. As a result of the conducted tests and on the basis of the respective calculations, an analysis of the obtained results was performed. Based on the analysis of the research findings, it can be concluded that the picks marked as Gold 25, Commercial 22, and Commercial 25 exhibited the lowest wear rates.

Below, the observations referring to the particular types of picks are presented:

- Commercial 22 and 25 (factory-manufactured picks) - achieved a very good performance result,

- Hardfaced 22 and 25 - despite the application of laser hardfacing, they exhibited a result which was slightly inferior to that of the factory-manufactured picks that had been used to produce them,

- Gold 25 - achieved the best result, still the titanium nitride coating only slightly increased their abrasion resistance,

- Silver 22 - despite the application of a special treatment to the body (the details of this process have not been disclosed), this achieved a result which was slightly inferior to that of the factory-manufactured picks that had been used to produce them,

- Casted 22 - casted pick, rolled after molding to meet the desired dimensions; the pick's bodies broke after fitting them with the sintered carbide inserts, and the picks at Stands 2 and 3 were broken off during testing,

- Ceramic - casted pick, rolled after molding to meet the desired dimensions, wore down extremely quickly despite the four-times smaller volume of the cut sample; the pick at Stand 2 chipped off, and the pick at Stand 3 broke at the holding part.

\section{CONCLUSION}

As can be seen from this paper, there are numerous ways to improve the durability and decrease the wear rate of tangential-rotary picks. Currently, the most- -commonly-used method that provides the best results is the hardfacing of the operational part with an abrasion-resistant layer. Nevertheless, as the conducted research indicates, it is not always the best solution. Moreover, it can be concluded that even the best protective coating will not serve its function if the pick or its cutting edge is manufactured with low-quality material.

Undoubtedly, further research aimed at improving the durability of picks should be recommended, as it has a significant influence on lowering operating costs and, consequently, prices of the mined raw materials.

\section{References}

[1] Krauze K.: Urabianie skat kombajnami ścianowymi, Wydawnictwo Naukowe Śląsk, Katowice 2002.

[2] Krauze K., Klempka R., Mucha K.: Computer-aided design of cutting heads, "Mining - Informatics, Automation and Electrical Engineering" 2015, 4: 22-32.

[3] Krauze K., Mucha K.: Zwiększenie odporności na zużycie ścierne noży kombajnowych, "Przegląd Górniczy" 2016, 1: 63-67.

[4] Jonak J.: Urabianie skat głowicami wielonarzędziowymi, Wydawnictwo Naukowe Śląsk, Katowice 2002.

[5] Kotwica K.: Effect of selected working conditions of cutting picks on their wear during the mining of hard rocks, "Quarterly Mechanics and Control" 2010, 29, 3: 110-119.

[6] Bołoz Ł.: Ocena obciażenia jednoorganowego kombajnu ścianowego na podstawie badań analitycznych [doctoral thesis], Kraków 2012.

[7] Kotwica K., Gospodarczyk P.: Hard Rock Mining with use of New Cutting Tools, "Journal of Mining Sciences" 2003, 39, 4: 387-393.

[8] Krauze K., Bołoz Ł., Wydro T.: Parametric factors for the tangential - rotary picks quality assessment, "Archives of Mining Sciences" 2015, 60, 1: 265-281.

[9] Krauze K., Bołoz Ł., Wydro T.: Ocena jakości noży styczno-obrotowych na podstawie badań laboratoryjnych, "Mechanizacja, Automatyzacja i Robotyzacja w Górnictwie: monografia 2012", Lędziny 2012.

[10] Krauze K., Skowronek T., Mucha K.: Influence of the hardfaced layer welded on tangential - rotary pick operational part on to its wear rate, "Archives of Mining Sciences" 2016, 61, 4: 779-792.

[11] Sandvik Coromant: http://www.sandvik.coromant.com (access: 24.04.2017)

[12] Kotwica K.: The influence of water assistance on the character and degree of wear of cutting tools applied in roadheaders, "Archives of Mining Sciences" 2011, 56, 3: 353-374.

KRZYSZTOF KRAUZE, Prof. ŁUKASZ BOŁOZ, Ph.D., Eng. TOMASZ WYDRO, Ph.D., Eng. KAMIL MUCHA, M.Sc., Eng. Faculty of Mechanical Engineering and Robotics AGH University of Science and Technology al. Mickiewicza 30, 30-059 Krakow, Poland \{krauze, boloz,wydro, kmucha\}@agh.edu.pl 